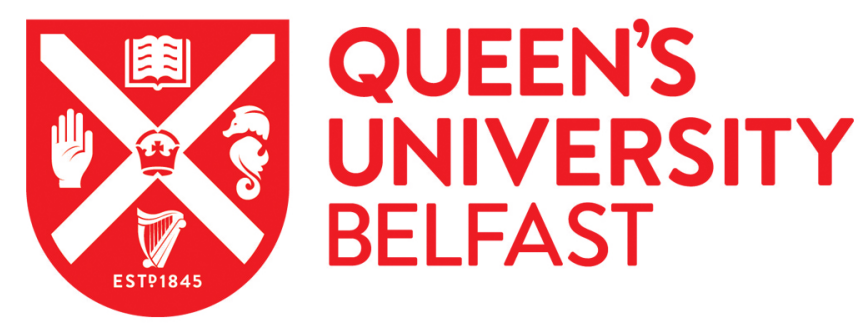

\title{
Reflexology: a randomised controlled trial investigating the effects on beta-endorphin, cortisol and pregnancy related stress.
}

mccullough, J. E. M., Liddle, S. D., Close, C., Sinclair, M., \& Hughes, C. M. (2018). Reflexology: a randomised controlled trial investigating the effects on beta-endorphin, cortisol and pregnancy related stress.

Complementary Therapies in Clinical Practice, 31, 76-84. https://doi.org/10.1016/j.ctcp.2018.01.018

\section{Published in:}

Complementary Therapies in Clinical Practice

\section{Document Version:}

Peer reviewed version

Queen's University Belfast - Research Portal:

Link to publication record in Queen's University Belfast Research Portal

\section{Publisher rights}

(C) 2018 Elsevier Ltd.

This manuscript version is made available under the CC-BY-NC-ND 4.0 license http://creativecommons.org/licenses/by-nc-nd/4.0/,which permits distribution and reproduction for noncommercial purposes, provided the author and source are cited

\section{General rights}

Copyright for the publications made accessible via the Queen's University Belfast Research Portal is retained by the author(s) and / or other copyright owners and it is a condition of accessing these publications that users recognise and abide by the legal requirements associated with these rights.

Take down policy

The Research Portal is Queen's institutional repository that provides access to Queen's research output. Every effort has been made to ensure that content in the Research Portal does not infringe any person's rights, or applicable UK laws. If you discover content in the Research Portal that you believe breaches copyright or violates any law, please contact openaccess@qub.ac.uk. 
Reflexology: a randomised controlled trial investigating the effects on beta-endorphin, cortisol and pregnancy related stress.

Julie EM McCullough PhD Institute of Nursing and Health Research, Ulster University, Shore Road, Newtownabbey, Co Antrim, Northern Ireland, BT37 OQB

j.mccullough@ulster.ac.uk

Twitter@jem mccullough

Sarah Dianne Liddle PhD Institute of Nursing and Health Research, Ulster University, Shore Road, Newtownabbey, Co Antrim, Northern Ireland, BT37 OQB

sd.liddle@ulster.ac.uk

Ciara Close PhD Centre for Public Health, Queens University, Belfast, Northern Ireland, BT9 7BL

c.close@qub.ac.uk

Marlene Sinclair Professor of Midwifery Institute of Nursing and Health Research, Ulster University, Shore Road, Newtownabbey, Co Antrim, Northern Ireland, BT37 0QB

m.sinclair1@ulster.ac.uk

Ciara M Hughes PhD Institute of Nursing and Health Research, Ulster University, Shore Road, Newtownabbey, Co Antrim, Northern Ireland, BT37 OQB

cm.hughes@ulster.ac.uk

This research was part funded by the Department of Employment and Learning, Northern Ireland.

\section{Highlights}

- Pregnant women use reflexology for a range of conditions

- Reflexology may be helpful for managing pregnancy related low back and /or pelvic girdle pain (LBPGP)

- This is the first investigation which attempts to quantify changes in beta-endorphin in response to a reflexology treatment

- The effect of reflexology on salivary beta-endorphin and cortisol concentrations during pregnancy is not yet fully known

- Further antenatal reflexology research is required to enable women and health care professionals to make informed decisions 


\begin{abstract}
Reflexology is used for various pregnancy related complaints. A three-armed, pilot randomized controlled trial was conducted to test changes in physiological and biochemical stress parameters. Ninety primiparous volunteers experiencing low back and /or pelvic girdle pain (LBPGP) were recruited to receive either six reflexology or footbath treatments or usual care. Primary outcome data included pain intensity and frequency measured on a visual analog scale (VAS), and salivary beta-endorphin and cortisol levels. 61 (68\%) women completed the intervention. A clinically important reduction of $1.63 \mathrm{~cm}$ occurred for VAS pain frequency following reflexology. Beta-endorphin levels increased by $8.8 \%$ and $10.10 \%$ in the footbath and usual care groups respectively and decreased by $15.18 \%$ for the reflexology group. Cortisol increased by $31.78 \%$ for footbath participants, $31.42 \%$ in usual care and $18.82 \%$ in the reflexology group. Reflexology during pregnancy may help reduce LBPGP, and associated stress. However, antenatal reflexology is under researched and requires further investigation.
\end{abstract}

Keywords Reflexology; beta-endorphin; cortisol; pregnancy; low back pain; pelvic girdle pain

\title{
1. Introduction
}

The mechanism of action of reflexology is not yet understood, however, studies have found a positive effect on quality of life, stress levels and painful conditions [1-4] and it may be helpful for reducing low back pain (LBP) in the general population [5-6]. Reflexology has also been shown to reduce stress markers such as salivary amylase [7] and cortisol [3,8] and a recent systematic review and meta-analysis has concluded that it may have a blood pressure (BP) lowering effect [9]. A popular hypothesis states that reflexology causes a release of endorphins in the body [10], and in this way promotes the associated feelings of health and wellbeing. However, to date, no studies have been identified that have tested this.

Cortisol and beta-endorphin are two of a number of hormones, involved in stress and the pain response. They are synthesised within the hypothalamus-pituitary-adrenal (HPA) cortex due to the release of corticotropin-releasing hormone (CRH) [11], which leads to the secretion of the pro-hormone pro-opiomelanocortin (POMC) by the pituitary gland. Cleavage of POMC leads to the production of ACTH in the pituitary, which stimulates the production of cortisol in the adrenal cortex and the release of beta-endorphin in the anterior pituitary gland.

Cortisol is released in response to chronic, prolonged physiological and psychological stress such as pain and apprehension [12]. Physiological effects of stress related increased levels of cortisol include decreased pain threshold [13] and elevated heart rate [14]. A correlation 
in cortisol levels between different body fluids (plasma, blood, urine and saliva) has been documented in both the general population and in pregnant women [15-17].

Beta-endorphin is released into the blood stream from the pituitary gland in response to episodes of acute pain and stress, [18-19] and is involved in reducing pain [20], the perception of pain and increasing pain threshold [21]. Beta-endorphin concentrations are commonly evaluated in blood, plasma or cerebrospinal fluid (CSF). There is conflicting evidence regarding what constitutes 'normal' levels of beta-endorphin in saliva for the general population [22-23] and expected plasma beta-endorphin changes during pregnancy [24-27] with no previous studies having been identified investigating salivary betaendorphin in the pregnant population.

One of the most common pregnancy related symptoms is low back pain and/or pelvic girdle pain (LBPGP) which is reported to cause considerable distress and functional limitations for women [28]. The incidence of pregnancy related LBP ranges from $66 \%$ up to $71 \%$ [29-30] and of pelvic girdle pain from $20 \%$ to $65 \%$ [29-30] with a typical increase in symptoms as pregnancy progresses [31-32]. This leads to an increase in physiological and psychological stress which alter BP, heart rate (HR), cortisol and beta-endorphin levels.

In order to evaluate any changes related to reflexology treatments during pregnancy a group of low risk pregnant women who were experiencing pain as a result of LBPGP were recruited. This investigation was part of a large pilot study reported elsewhere [33] to evaluate strategies aimed at preventing or managing LBPGP during pregnancy as few guidelines are available, and with physiotherapy being the primary intervention in most cases. Literature reviews have highlighted that CAM may be helpful for managing this type of pain [30,34]. However, these reviews also indicated that reflexology had not yet been investigated as a management strategy. This lack of evidence is of concern to healthcare professionals given that reflexology is currently being used in maternity settings. As many women are unlikely to disclose their use of CAM to their midwife or doctor, the effectiveness and the safety of this treatment requires proper investigation [35-36]. This trial is the first of its kind to investigate the potential changes in salivary cortisol and betaendorphin levels in pregnant women following the delivery of a complementary and alternative medicine (CAM) intervention.

\section{Materials and methods}

This trial was listed with the International Standard Randomised Controlled Trial Number Register (ISRCTN26607527), and ethical approval was granted by the Office for Research Ethics Committees Northern Ireland (12/NI/0052, 5 July 2012). The trial, known as the CAM in Pregnancy Trial, ran from July 2012 until December 2013, with primiparous participants recruited from a large inner city maternity out-patients department at their routine 20 week anomaly scan. Using computer generated block randomisation and sealed opaque 
envelopes, all eligible participants (Table 1) were randomised into one of three arms of the study; reflexology (intervention), footbath (sham treatment), to control for the patienttherapist interaction, and usual ante-natal care (control group). This study has been reported elsewhere including additional study outcome data, including feasibility, recruitment and retention, and details of the reflexology and footbath procedures [37-39].

The reflexology and footbath group participants were asked to provide a $2 \mathrm{ml}$ saliva sample via passive drool into cryovials approximately 10 minutes before and after their first and last treatment. Those in the usual care group were asked to provide $2 \mathrm{ml}$ saliva samples, at the initial baseline interview and 6 weeks later. All saliva samples were kept on ice to avoid any microbial growth. Samples were held for a maximum of 5 hours before being transported to a $-80^{\circ} \mathrm{C}$ freezer. Participants and therapists were not blinded to treatment allocation in this study, however, to minimise bias, an independent researcher otherwise uninvolved in the study recoded all of the completed questionnaires and saliva samples prior to analysis by the researchers.

\subsection{Outcome measures}

Patient reported outcome measures were completed by the participant alone and analysed by a researcher blinded to the intervention. A $0-10 \mathrm{~cm}$ Visual Analogue Scale (VAS) for pain intensity and frequency was completed at baseline and weekly by those in the intervention group. A change on the VAS scale of $15 \mathrm{~mm}$ is regarded as clinically significant [40]. The State Trait Anxiety Inventory S-subscale Questionnaire (STAI-S) [41] was completed by all participants at baseline and end of intervention. A score of 39-40 on the S-anxiety scale may detect clinically significant symptoms [42-43] and is categorised as highly anxious [44].

Before and after each treatment participants in the footbath and reflexology groups had their BP and HR checked and recorded (Omron M2 Basic Blood Pressure Monitor, Omron Corporation, Kyoto, Japan), with participants resting either seated (footbath group) or reclined (reflexology group). In order to reduce the possibility of white coat syndrome the therapists wore black tunics while carrying out all the treatments to negate any effect of increasing BP [45]. Usual care participants did not have their BP and HR measured weekly as it would not be routine or normal practice and therefore it would have created an unnecessary burden on participants.

Before each treatment a screening questionnaire was completed to ensure that no contraindications to treatment had developed and to collect data on any medications or interventions that had been used by the participant in the previous week to manage their pain, or any changes or benefits they had noticed. This information was also collected from women in the usual care group via completion of weekly diary.

\subsection{Saliva sampling}


All participants had their non-smoking status confirmed (Bedfont Pico Smokerlyzer, Bedfont Scientific Ltd., Maidstone, England) as cigarette smoking can interfere with salivary cortisol analysis [46]. Participants were asked to fast for one hour before sampling in order to limit any fluctuations in $\mathrm{pH}$ which may interfere with the assay procedure [47]. Participants were also asked to avoid brushing their teeth for three hours before sampling to avoid any likelihood of oral damage leading to blood contamination and to refrain from alcohol for 24 hours. Before sampling the mouth was rinsed with water in order to clean away any particulates or residue to avoid contamination and interference with chemical biomarkers. A saliva sample was produced into cryovial (Salimetrics) by passive drool. Samples were stored in $\mathrm{a}-80^{\circ} \mathrm{C}$ freezer until analysis at which point they were slowly brought back to room temperature (RT), vortexed and centrifuged at 3000g for 15 minutes. Enzyme Immunosorbant Assay (EIA) was used to determine the cortisol (Salimetrics, State College, Pennsylvania/Suffolk England) and beta-endorphin (Bachem, Peninsula Laboratories, LLC, San Carlos, California) concentrations in samples.

\subsection{Interventions}

The reflexology routine was based on the works of Enzer [48], Marquardt [49] and Tiran [50]. All reflexology treatments were carried out by one experienced maternity reflexologist and lasted for approximately 30 minutes. Details of the treatment routine have been reported elsewhere [33].

The foot bath intervention participants placed their feet in a purpose-made plastic basin containing comfortably warm water and decorative stones to increase the aesthetic value of the treatment. The water was topped up as required to maintain the temperature and treatments also lasted approximately 30 minutes. All other conditions were standardised between the two intervention groups including the music played during the treatments, the attire of the therapists, room temperature, waiting area, and public facilities available. Usual care participants followed the usual antenatal care provided by their maternity health care providers.

\subsection{Statistics}

No power calculation was completed for this study as the main objective was to pilot the methods and procedures. Descriptive statistics, correlations, ANOVA and paired samples ttests were completed. Data was analysed using Statistical Package for the Social Sciences (SPSS) Version 24. Data was analysed for incompleteness and whether missing values were missing completely at random (MCAR) using Littles MCAR test. To reduce bias in the analysis, where an outcome measure had less than $10 \%$ missing data the missing values were input using the multiple imputation (MI) method [51]. Analysis using SPSS showed that the cortisol and beta endorphin baseline data was not normally distributed. Therefore, non-parametric tests were carried out. 


\section{Results}

An eligible sample of 428 pregnant women were informed of the study at their 20 -week appointment and 262 information and consent forms were distributed. Of the 100 women who consented to take part one was excluded as she was a smoker and 90 attended for the baseline meeting and randomisation. Of these 61 (67.8\%) completed at least four treatments, end of intervention questionnaires and the requested saliva samples. Final numbers were 23 participants each in the reflexology and usual care groups and 15 footbath participants (Figure 1).

\subsection{Baseline Data}

Table 2 shows the demographic data collected at the first saliva sample collection time point. Analysis of baseline data using paired-samples t-test and One Way ANOVA demonstrated no difference between the groups at baseline.

\subsection{Physiological outcome measures}

The results from this study found that there were no changes in HR for either treatment group or between groups ( $p=0.865)$. Minimal changes in SBP were recorded, with an increase of $3 \mathrm{mmHg}$ for the footbath group and no change for the reflexology group. Results for $\mathrm{dBP}$ showed an increase of $1.4 \mathrm{mmHg}$ for both treatment groups over the course of a sixweek intervention. There was no significant difference between groups for $s B P(p=0.311)$ or $\mathrm{dBP}(\mathrm{p}=0.085)$.

\subsection{Pain and stress outcomes}

There was a clinically significant reduction $(1.63 \mathrm{~cm})$ in VAS pain frequency for the reflexology group over the six-week intervention period but not for pain intensity (Table 3). No clinically important changes were observed in the footbath or usual care groups.

State anxiety was high at baseline (Table 2) indicated by a STAI result greater than or equal to 40 [52-53]. Over the course of the trial anxiety levels remained fairly static with no change for the usual care participants and a small increase for the footbath and reflexology participants.

\subsection{Biochemical outcome measures}

Individual participant samples were collected at the same time of day to reduce within participant variation. Over the six-week intervention period beta-endorphin levels increased by $8.8 \%$ and $10.10 \%$ in the footbath and usual care groups respectively and decreased by $15.18 \%$ for the reflexology group (Table 4/Figure 2). Cortisol increased by 
$31.78 \%$ in the footbath group, $31.42 \%$ in usual care and $18.82 \%$ in the reflexology group from baseline to the end of the six-week intervention period (Table 5/Figure 3). However, there were no significant differences between groups for cortisol $(p=0.935)$ or betaendorphin $(p=0.251)$. Saliva samples collected before and after treatment one and treatment six showed a within treatment trend for a reduction in salivary beta-endorphin concentration for reflexology and an increase in response to a footbath treatment; this trend was not observed for cortisol response. However, the standard deviations for all the saliva analysis results were very high and indicate that further investigation is required.

There was no correlation between beta-endorphin or cortisol levels and any other outcome variable.

\subsection{Other findings}

Additional data was collected from weekly screening questionnaires from the intervention participants and diaries from the usual care participants. Forty percent of the participants used medications to manage their LBPGP and there was little difference between groups. However, women with some form of PP tended to use more over the counter (OTC) medications which included paracetamol, co-codamol, ibuprofen and Volterol (diclofenac).

Producing saliva was difficult for $100 \%$ of participants at some stage during the study and resulted in one woman in the reflexology group being lost to follow up as she could not produce her final sample.

Women in the footbath and particularly the reflexology groups reported that they had found the treatments they received and the time spent with the therapist to be very relaxing and enjoyable. Some of the participants reported mild tenderness on certain areas of the feet during the reflexology treatments. No other adverse effects occurred.

\section{Discussion}

This pilot RCT was designed to investigate the use of complementary therapies in a typical clinical setting. This complex intervention investigated quantitative physiological and biochemical outcomes. Close et al. [33, 37-38] and McCullough et al. [39] have reported elsewhere on findings relating to the feasibility of the study, recruitment and retention, and additional data including patient reported pain and disability and labour outcomes. However, the small sample size was insufficient to demonstrate statistically significant differences between groups or the true effect of reflexology versus a sham treatment and, therefore, a larger study is warranted.

\subsection{Physiological findings}


While a reduction in BP due to increased levels of progesterone in the first 18-20 weeks of pregnancy is well documented, BP gradually increases to pre-pregnancy levels during the third trimester [54-56]. Reflexology has been reported to have a BP lowering effect [9], however, the six week course of reflexology and footbaths in the third trimester of pregnancy found only a small increase for SBP and dBP. HR increases throughout pregnancy [57-58]; however, there was no recorded increase, or a notable decrease in heart rate, which is a common effect of relaxation, for either of the treatment groups. It is possible that the cardiovascular effects of reflexology and footbath treatments may have been masked by participants advancing gestation.

\subsection{Psychological findings}

Elevated stress levels are a feature of pregnancy [59] and LBPGP has been shown to be positively correlated with increased stress and anxiety [60-61]. Therefore, the experience of LBPGP and the associated impact on daily life increases stress, exacerbating painful conditions [62-63] and increasing pain intensity [64]. A cycle of physiological pain and psychological stress ensues leading to biochemical responses. Firstly, due to initial low level pain and active stress, beta-endorphin is released [65-67], followed by cortisol release as the cycle continues into the chronic phase [68-69]. Meanwhile HR and BP become elevated due to the effects of stress [70].

Researchers investigating the use of CAM interventions during pregnancy have repeatedly reported that stress is reduced [71]. However, in the current study no correlation between STAI and stress hormones was found. As the STAI scores remained fairly static across the three groups this would indicate that the STAI was not a sensitive outcome measure for this population. Reductions in pain were observed as VAS for pain frequency increased in the footbath group and decreased in the reflexology and usual care groups, however, the reduction in the reflexology group was a clinically important change of $1.63 \mathrm{~cm}$. A change on the VAS pain scale of $1.5 \mathrm{~cm}$ or more is classified as a clinically important change [40, 72], this is a change which can be felt by the patient and provides them with some relief [73]. However, what constitutes a clinically important change in LBPGP during pregnancy is unknown as this has not yet been investigated. Pain perception varies widely between individuals and women's perceptions of pain are altered during pregnancy due to biochemical changes [74-75].

\subsection{Biochemical findings}

The results from this study have been the first attempt to test the popular hypothesis that reflexology works to reduce pain by initiating the release of beta-endorphin [10]. Kaada and Torsteinb $\varnothing[76]$ found an increase in beta-endorphin with connective tissue massage, however, this is a deeper, often uncomfortable manipulative therapy [77] which would not be of the type performed by reflexologists. While the current study found a reduction in pain, it did not support the endorphin release hypothesis as a mechanism of action for this 
effect, as the results demonstrated a reduction in beta-endorphin levels after a single treatment and also following a course of six weekly treatments. No definitive conclusion can be drawn due to the small numbers included in this study and the high within group variation in results; however, this beta-endorphin reducing effect corresponds to recent research involving healthy participants who received massage [78] which is an integral part of a reflexology treatment. Beta-endorphin was also found to be reduced as pain decreased after temporal mandibular joint (TMJ) surgery [79].

Massage has also been found to reduce cortisol [80-81]. Cortisol is known to increase as a normal part of pregnancy; the increase of $31.42 \%$ in cortisol levels for the usual care participants correlated to the findings of Suri, et al. [16] who demonstrated a $30.56 \%$ increase in salivary cortisol from the second to third trimester. Cortisol is essential for foetal organ maturation [82] during normal healthy pregnancy and levels are well documented [26, 83-84]. Therefore, while this study aimed to evaluate whether reflexology could reduce cortisol synthesis, an overall reduction from baseline was not expected. Instead, a reduced cortisol concentration in the treatment groups compared to the usual care group was found, suggesting that the nature of the footbath and to a greater extent reflexology led to a reduction in cortisol response. The reduced cortisol synthesis in the reflexology group is unlikely to have any detrimental effects on the foetus or mother as the detected levels were well within normal limits. The results suggest that reflexology induced positive feelings of wellbeing, which is linked to a lowered cortisol response [85], and the observed reduction in pain may have led to a deactivation of the HPA axis reducing the synthesis of betaendorphin and cortisol. Therefore, the overall positive experience of reflexology may have been the mechanism affecting the HPA axis.

The patient-therapist interaction certainly had an impact on the outcomes of this trial. This would not only be expected but encouraged as rapport is critical to the overall delivery of reflexology and CAM in general. It is likely that associated reactions to the social support facet of reflexology, which have been found to increase pain threshold [86], may have altered women's experience of their pain during the trial. Biochemical and physiological changes associated with touch therapies, most likely led to the positive outcomes and high participant satisfaction of this study. This or hormonal changes as a result of normal pregnancy and elevated levels may have altered the process by which beta-endorphin is released in the body. Any changes in biochemical and physiological responses due to participant-therapist interaction or the placebo effect further demonstrate that they are integral to the mode of action of CAM therapies in general and is an area requiring further investigation.

Reflexology has been found to significantly improve tiredness during pregnancy [87] and since many of the women reported better sleep after reflexology this may have also led to the reduction in stress hormones. Sleep was not formally measured as part of the current 
study; therefore, future investigations into this benefit are warranted given that sleep disruption negatively affects health and wellbeing.

\subsection{Limitations}

There are several limitations to this study notably the small sample size of self-selecting women who may not representative of the general pregnant population. Pain frequency at baseline was higher for the reflexology participants compared to the other two groups. This was not statistically significant; however, it may have influenced results. Confounding factors such as spontaneous remission, patient or medical personnel biases, regression to the mean or the effect of unidentified co-interventions may have been responsible for the changes reported. The consumption of alcohol and caffeine [88-89] and waking time may have had an impact on cortisol and beta-endorphin levels. The influence that of any of these factors may have had on outcomes was not investigated as part of this study. In addition, Suri, et al. [16] and DiPietro et al. [90] state that daily cortisol levels fluctuate but overall they increase so, given that the cortisol results only give levels for a single point in time, these specific time points may have been minor natural fluctuations in cortisol levels unrelated to the treatment received. Also, cortisol response to stress during pregnancy is related to the stage of pregnancy [91]. The wide variation in beta-endorphin concentrations within the groups prevents any firm conclusions being drawn at this time. In addition, it would have been preferable to also measure BP and HR in the usual care group to compare and contrast with the findings from the reflexology and foot bath groups.

Pregnant women were keen to experience reflexology. A lack of participant blinding to the trial interventions under investigation, which could not be avoided given the nature of this study, resulted in $97 \%$ of those women randomised to assert that they would have preferred to be allocated to the reflexology arm of the trial. Prior to randomisation there was significantly lower expectations for the helpfulness of footbath compared with reflexology. Blinding in trials of this nature is known to be problematic and is a factor contributing to bias in future trials where the control measure is not mutually acceptable to participants. Furthermore, the participant-therapist interaction, which is an integral part of CAM therapies, will also have affected physiological and biochemical results. The high rates of attrition and the reasons for this may also have influenced results and this has been discussed elsewhere [37].

Collection and analysis of saliva is known to be quick and simple to carry out and, therefore, was chosen as it is less invasive than blood collection, which may have had an impact on the stress hormones under investigation. However, all of the pregnant participants found the process of expectorating saliva into the collection tubes troublesome, frustrating and 'messy'. Many also had difficulty producing enough saliva, with one woman failing to do so, stating that it made them feel nauseous. This condition had not been previously reported during pregnancy or saliva collection from pregnant women. 


\section{Conclusion}

These results suggest that the nature of reflexology may have acted to reduce pain, disrupting the cycle of pain and stress leading to a reduction the stress related release of cortisol and beta-endorphin over a six-week intervention period. It is also possible that other biochemicals released in response to reflexology lead to a down regulation of betaendorphin.

This study was underpowered to provide definitive conclusions regarding findings, however, the trends in the reduction in stress hormones adds much needed quantitative evidence for the effects of reflexology and the use of reflexology during pregnancy and highlights the need for further investigation in the area. The extent of any benefits that this inexpensive, non-pharmacological, non-invasive, safe, patient preferred treatment can offer to pregnant women and the general population have clearly yet to be elucidated.

\section{Competing Interests}

The authors declare that there is no conflict of interest regarding the publication of this paper.

\section{Acknowledgments}

The authors wish to thank all of the women who took part in this research, and the midwives and staff at the Ulster Hospital, Northern Ireland. Thanks also to the late Professor George Lewith for his expert advice with this work and Dr Paul Slater and Professor lan Bradbury for their statistical advice.

\section{References}

1. Stephenson, N.L.N., Weinrich, S.P. and Abbas S. Tavakoli, A.S. (2000) The Effects of Foot Reflexology on Anxiety and Pain in Patients With Breast and Lung Cancer. Oncology Nursing Forum, 27 (1)

2. Hughes, C.M., Smyth, S. and Lowe-Strong, A.S. (2009) Reflexology for the treatment of pain in people with multiple sclerosis: a double-blind randomised sham-controlled clinical trial. Multiple Sclerosis Journal, 15(11), 1329-1338

3. Hodgson NA, Lafferty D. (2012) Reflexology versus Swedish massage to reduce physiologic stress and pain and improve mood in nursing home residents with cancer: A pilot trial. Evidence Based Complementary and Alternative Medicine, doi: 10.1155/2012/456897 Article ID: 456897

4. Wyatt, G., Sikorskii, A., Rahbar, M.H., Victorson, D. and You, M. (2012) Health related quality-of-life outcomes: a reflexology trial with patients with advanced-stage breast cancer. Oncology Nursing Forum, 39 (6), 568-577.

5. Quinn, F., Hughes, C. M. and Baxter, G. D. (2008). Reflexology in the management of low back pain: a pilot randomised controlled trial. Complementary Therapies in Medicine, 16(1), 3-8.

6. Eghbali, M., Safari, R., Nazari, F. and Adboli, S. (2012) The effects of reflexology on chronic low back pain intensity in nurses employed in hospitals affiliated with Isfahan 
University of Medical Sciences. Iranian Journal of Nursing and Midwifery Research; 17(3): 239-243.

7. Hodgson, N.A. and Andersen, S. (2008) The clinical efficacy of reflexology in nursing home residents with dementia. The Journal of Alternative and Complementary Medicine 14(3), 269-275.

8. Mackereth, P.A., Booth, K., Hillier, V.F. and Caress, A.L. (2009) Reflexology and progressive muscle relaxation training for people with multiple sclerosis: a crossover trial. Complementary Therapy in Clinical Practice, 15, (1), 14-21.

9. McCullough, J.E.M., SD Liddle, Sinclair M, Close C, Hughes CM (2014) The Physiological and Biochemical Outcomes Associated with a Reflexology Treatment: A Systematic Review. Evidence-Based Complementary and Alternative Medicine. Available online at: http://www.hindawi.com/journals/ecam/2014/502123/cta/

10. Tiran, D. and Chummun, H. (2004) Complementary therapies to reduce physiological stress in pregnancy. Complementary Therapies in Nursing \& Midwifery, 10, 162-167.

11. Kunugi, H., Hori, H., Adachi, N. and Numakawa, T. (2010) Interface between hypothalamic-pituitary-adrenal axis and brain-derived neurotrophic factor in depression. Psychiatry and Clinical Neurosciences, 64 (5), 447-459.

12. Russell, E., Koren, G., Rieder, M. and Van Uum, S. (2012) Hair cortisol as a biological marker of chronic stress: Current status, future directions and unanswered questions. Psychoneuroendocrinology, 37 (5), 589-601.

13. Choi, J.C., Chung, M.I. and Lee, Y.D. (2012) Modulation of pain sensation by stressrelated testosterone and cortisol. Anaesthesia, 67(10), 1146-1151.

14. Looser, R.R., Metzenthin, P., Helfricht, S., Kudielka, B.M., Loerbroks, A., Thayer, J.F. and Fischer, J.E., 2010. Cortisol is significantly correlated with cardiovascular responses during high levels of stress in critical care personnel. Psychosomatic Medicine, 72(3), pp.281-289.

15. Umeda, T., Hiramatsu, R., Iwaoka, T., Shimada, T., Miura, F. and Sato, T. (1981) Use of saliva for monitoring unbound free cortisol levels in serum. Clinica Chimica Acta, 110, 245-253.

16. Suri, D., Moran, J., Hibbard, J.U., Kasza, K. and Weiss, R.E. (2006) Assessment of adrenal reserve in pregnancy: defining the normal response to the adrenocorticotropin stimulation test. Journal of Clinical Endocrinology and Metabolism, 91, 3866-3872.

17. Sakihara, S., Kageyama, K., Oki, Y., Doi, M., Iwasaki, Y., Takayasu, S., Moriyama, T., Terui, K., Nigawara, T., Hirata, Y., Hashimoto, K. and Suda, T. (2010) Evaluation of plasma, salivary, and urinary cortisol levels for diagnosis of Cushing's syndrome. Endocrine Journal, 57, (4), 331-337.

18. Sheps, D.S., Ballenger, M.N., De Gent, G.E., Krittayaphong, R., Dittman, E., Maixner, W., McCartney, W., Golden, R.N., Koch, G. and Light, K.C. (1995). Psychophysical responses to a speech stressor: Correlation of plasma beta-endorphin levels at rest and after psychological stress with thermally measured pain threshold in patients with coronary artery disease. Journal of American College of Cardiology, 25 (7), 1499-1503.

19. Sprouse-Blum, A.S., Smith, G., Sugai, D. and Parsa, D.F. (2010) Understanding endorphins and their importance in pain management. Hawaiian Medical Journal, 69, (3), 70-71. 
20. Hartwig, A.C. (1991) Peripheral beta-endorphin and pain modulation. Anesthesia Progress. 38(3): 75-78.

21. Jarmukli, N.F., Ahn, J., Iranmanesh, A. and Russell, D.C. (1999) Effect of raised plasma beta-endorphin on peripheral pain and angina thresholds in patients with stable angina. Heart, 82, 204-209.

22. Takai, N., Yamaguchi, M., Aragaki, T., Eto, K., Uchihashi, K. and Nishikawa, Y. (2007) Gender-specific differences in salivary biomarker responses to acute psychological stress. Annals of the New York Academy of Sciences, 1098, 510-515.

23. Rai, B. and Kaur, J. (2011) Salivary stress markers and psychological stress in simulated microgravity: 21 days in $6^{\circ}$ head-down tilt. Journal of Oral Science, 53 (1), 1343-4934.

24. Hoffman, D.I., Abboud, T.K., Haase, H.R., Hung, T.T. and Goebelsmann, U. (1984) Plasma beta-endorphin concentrations prior to and during pregnancy, in labor, and after delivery. American Journal of Obstetrics and Gynecology, 150(5 Pt 1), 492-496.

25. Abboud, T.K. (1988) Maternal and fetal beta endorphin: effects of pregnancy and labour. Archives of Disease in Childhood, 63, 707 -709.

26. Chan, E.C., Smith, R., Lewin, T., Brinsmead, M.W., Zhang, H.P., Cubis, J., Thornton, K. and Hurt, D. (1993) Plasma corticotropin-releasing hormone, beta-endorphin and cortisol inter-relationships during human pregnancy. Acta Endocrinol (Copenh), 128(4), 339-344.

27. De Punzio, C., Neri, E., Metelli, P., Bianchi, M.S., Venticinque, M., Ferdeghini, M. and Fioretti, P. (1994) The relationship between maternal relaxation and plasma betaendorphin levels during parturition. Journal of Psychosomatic Obstetrics and Gynaecology, 15(4), 205-210.

28. Sinclair, M., Close, C., McCullough, J.E.M., Hughes, C.M. and Liddle, S.D. (2014) How do women manage pregnancy-related low back and/or pelvic pain? Descriptive findings from an online survey. Evidence Based Midwifery, 12 (3), 76-82.

29. Kovacs FM, Garcia E, Royuela A, González L, Abraira V; Spanish Back Pain Research Network (2012) Prevalence and factors associated with low back pain and pelvic girdle pain during pregnancy: a multicenter study conducted in the Spanish National Health Service. Spine (Phila Pa 1976). 2012 Aug 1;37(17):1516-33.

30. Liddle SD, Pennick V. Interventions for preventing and treating low-back and pelvic pain during pregnancy. Cochrane Database Syst Rev. 2015;9:CD001139.

31. Vermani, E., Mittal R. and Weeks, A. (2010) Pelvic girdle pain and low back pain in pregnancy: a review. Pain Practice, 10 (1), 60-71.

32. Nazik, E. and Eryilmaz, G. (2013) Incidence of pregnancy-related discomforts and management approaches to relieve them among pregnant women. Journal of Clinical Nursing, 23, 1736-1750.

33. Close, C., McCullough, J.E.M., Sinclair, M., Liddle, S.D. and Hughes, C.M. (2015) A pilot randomised controlled trial investigating the effectiveness of reflexology for managing pregnancy low back and pelvic pain. Complementary Therapies in Clinical Practice, http://dx.doi.org/10.1016/j.ctcp.2015.05.00

34. Close, C., Sinclair, M., Liddle, S.D., Madden, E., McCullough, J.E.M. and Hughes, C.M. (2014) A systematic review investigating the effectiveness of Complementary and Alternative Medicine (CAM) for the management of low back and/or pelvic pain (LBPP) in pregnancy. Journal of Advanced Nursing, 70(8), 1702-1716. 
35. Hall, H.R. and Jolly, K. (2014) Women's use of complementary and alternative medicines during pregnancy: A cross-sectional study. Midwifery, 30(5), 499-505.

36. Warriner, S., Bryan, K. and Brown, A.M. (2014) Women's attitude towards the use of complementary and alternative medicines (CAM) in pregnancy. Midwifery, 30(1), 138-143.

37. Close, C., Sinclair, M., McCullough, J.E.M., Liddle, D. and Hughes, C. (2016) Factors Affecting Recruitment and Attrition in Randomised Controlled Trials of Complementary and Alternative Medicine for Pregnancy-Related Issues. EvidenceBased Complementary and Alternative Medicine, 2016. http://dx.doi.org/10.1155/2016/6495410

38. Close, C., Sinclair, M., Liddle, D., McCullough, J. and Hughes, C. (2016) Women's experience of low back and/or pelvic pain (LBPP) during pregnancy. Midwifery, 37, 18.

39. McCullough, J.E.M, Close, C., Liddle, S.D., Sinclair, M. and Hughes, C.M. (2017) Results from a pilot randomised controlled trial exploring the effects of antenatal reflexology on labour outcomes. Midwifery, 55, 137-144.

40. Gallagher, E.J., Liebman, M. and Polly E. Bijur, P.E. (2001). Prospective validation of clinically important changes in pain severity measured on a visual analog scale. Annals of Emergency Medicine, 38(6) 633-638.

41. Spielberger, C.D., Gorsuch, R.L., Lushene, P.R., Vagg, P.R. and Jacobs, A.G. (1983) Manual for the State-Trait Anxiety Inventory (Form Y). Available at: faculty.sjcny.edu/.../State\%20Trait\%20Anxiety\%20Inventory.doc. Accessed 10th January 2012

42. Knight, R.G., Waal-Manning, H.J. and Spears, G.F. (1983) Some norms and reliability data for the State-Trait Anxiety Inventory and the Zung Self-Rating Depression scale. British Journal of Clinical Psychology, 22(4), 245-249.

43. Addolorato, G., Ancona, C., Capristo, E., Graziosetto, R., Di Rienzo, L., Maurizi, M. and Gasbarrini, G. (1999) State and trait anxiety in women affected by allergic and vasomotor rhinitis. Journal of Psychosomatic Research, 46(3), 283-289.

44. Grant, K.A., McMahon, C. and Austin, M.P. (2008) Maternal anxiety during the transition to parenthood: A prospective study. Journal of Affective Disorders, 108 (1-2), 101-111.

45. Muxfeldt ES, Bloch KV, Nogueira AR, Salles GF. (2003) Twenty-four hour ambulatory blood pressure monitoring pattern of resistant hypertension. Blood Pressure Monitoring, 8(5), 181-185.

46. Kirschbaum, C., Wust, S. and Strasburger, C.J. (1992) 'Normal' cigarette smoking increases free cortisol in habitual smokers. Life Sciences, 50: (6) 435-442.

47. Schwartz E.B., Granger D.A., Susman E.J., Gunnar M.R. and Laird B. (1998) Assessing Salivary Cortisol in Studies of Child Development. Child Development, 69 (6) 15031513.

48. Enzer, S. (2004) Maternity reflexology manual. 2nd ed. England: Soul to Sole Reflexology Limited.

49. Marquardt, H. (2007) Reflex zone therapy of the feet: A comprehensive guide for health professionals. Healing Arts Press, Vermont.

50. Tiran, D. (2010) Reflexology in pregnancy and childbirth. London: Churchill Livingstone Elsevier. 
51. Bennett DA. How can I deal with missing data in my study? (2001) Australian and New Zealand Journal of Public Health, 25(5),464-469.

52. Teixeira, J.M.A., Fisk, N.M. and Glover, V. (1999) Association between maternal anxiety in pregnancy and increased uterine artery resistance index: cohort based study. BMJ. 318(7177), 153-157.

53. Newham, J.J., Wittkowski, A., Janine Hurley, J., Aplin, J.D. and Westwood, M. (2014) Effects of antenatal yoga on maternal anxiety and depression: a randomized controlled trial. Depression And Anxiety 00:1-10. http://onlinelibrary.wiley.com/doi/10.1002/da.22268/full 18/7/14

54. Deak, T.M. and Moskovitz, J.B. (2012) Hypertension and pregnancy. Emergency Medicine Clinics of North America, 30(4), 903-917.

55. Mustafa, R., Ahmed, S., Gupta, A. and Venuto, R.C. (2012) A Comprehensive Review of Hypertension in Pregnancy. Journal of Pregnancy. 2012; 2012: 105918. Published online May 23, 2012. doi: 10.1155/2012/105918 accessed 13/5/14

56. Kattah, A.G. and Garovic, V.D. (2013) The management of hypertension in pregnancy. Advances in Chronic Kidney Disease, 20(3), 229-239.

57. Hall, M.E. George, E.M. and Granger, J.P. (2011) The heart during pregnancy. Revista Espanola de Cardiologia (English Edition), 64 (11), 1045-1050.

58. Ouzounian, J.G. and Elkayam, U. (2012) Physiologic Changes During Normal Pregnancy and Delivery. Cardiology Clinics-Cardiovascular Disease in Pregnancy, 30 (3), 317-329.

59. El-Bsat, R.M. (2014) Study Regarding the Benefits of Applying Hospital AnxietyDepression Scale (HAD) in Athletes During Pregnancy, 3rd International Congress on Physical Education, Sport and Kinetotherapy (ICPESK 2013). Procedia - Social and Behavioral Sciences, 117 (19) 566-569.

60. Andersson, G.B.J. (1999) Epidemiological features of chronic low-back pain. The Lancet, 354 (9178), 581-585.

61. Bener A, Verjee M, Dafeeah EE, Falah O, Al-Juhaishi T., SchlogI J, Sedeeq A. and Khan $S$ (2013) Psychological factors: anxiety, depression, and somatization symptoms in low back pain patients. Journal of Pain Research, 6, 95-101.

62. Rhudy, J.L. and Meagher, M.W. (2000) Fear and anxiety: Divergent effects on human pain thresholds. Pain, 84 (1), 65-75.

63. Reinhardt, T., Kleindienst, N. and Treede, R.-D. (2013) Individual Modulation of Pain Sensitivity under Stress. Pain Medicine (United States), 14 (5), 676-685.

64. Tang, J. and Gibson, S.J. (2005) A Psychophysical evaluation of the relationship between trait anxiety, pain perception, and induced state anxiety. The Journal of Pain, 6 (9) 612-619.

65. Dunbar, R.I.M. (2010) The social role of touch in humans and primates: Behavioural function and neurobiological mechanisms. Neuroscience \& Biobehavioral Reviews, 34 (2), 260-268.

66. Graignic-Philippe, R., Dayan, J., Chokron, S., Jacquet, A-Y. and Tordjman, S. (2014) Effects of prenatal stress on fetal and child development: A critical literature review. Neuroscience and Biobehavioral Reviews, 43, 137-162.

67. Veening, J.G. and Barendregt, H.P. (2015) The Effects of Beta-Endorphin: State Change Modification. Fluids and Barriers of the CNS, 12 (3)

68. Boudarene, M., Legros, J.J. and Timsit-Berthier, M. (2002) Study of the stress response: role of anxiety, cortisol and DHEAs. L'Encephale, 28(2), 139-146. 
69. Jacobs, N., Myin-Germeys, I., Derom, C., Delespaul, P., van Os, J. and Nicolson, N.A. (2007) A momentary assessment study of the relationship between affective and adrenocortical stress responses in daily life. Biological Psychology, 74 (1), 60-66.

70. Esler, M., Eikelis, N., Schlaich, M., Lambert, G., Alvarenga, M., Dawood, T., Kaye, D., Barton, D., Pier, C., Guo, L., Brenchley, C., Jennings, G. and Lambert, E. (2008) Chronic mental stress is a cause of essential hypertension: presence of biological markers of stress. Clinical and Experimental Pharmacology and Physiology, 35(4), 498-502.

71. Newham, J.J.,et al.,State-trait anxiety inventory (STAI) scores during pregnancy following intervention with complementary therapies. Journal of Affective Disorders(2012),http://dx.doi.org/10.1016/j.jad.2012.04.027 Accessed 26th March 2014.

72. Ostelo, R.W., Deyo, R.A., Stratford, P., Waddell, G., Croft, P., Von, K.M., Bouter, L.M. and de Vet, H.C. (2008) Interpreting change scores for pain and functional status in low back pain: towards international consensus regarding minimal important change, Spine, 33 (1), 90-94.

73. Farrar, J.T., Portenoy, R.K., Berlin, J.A., Kinman, J.L. and Strom, B.L. (2000) Defining the clinically important difference in pain outcome measures. Pain, 88(3), 287-294.

74. Gintzler, A.R. and Liu, N.H. (2001) The maternal spinal cord: biochemical and physiological correlates of steroid-activated antinociceptive processes. Progress in Brain Research, 133, 83-97.

75. Draisci, G., Catarci, S., Vollono, C., Zanfini, B.A., Pazzaglia, C., Cadeddu, C., Virdis, D. and Valeriani, M. (2012) Pregnancy-induced analgesia: a combined psychophysical and neurophysiological study. European Journal of Pain, 16: 1389-1397.

76. Kaada, B. and Torsteinb $\varnothing$, O. (1989) Increase of plasma beta-endorphins in connective tissue massage. General Pharmacology, 20 (4), 487-489.

77. Goats, G.C. and Keir, K.A. (1991) Connective tissue massage. British Journal of Sports Medicine, 25(3), 131-133.

78. Morhenn, V., Beavin, L.E. and Zak, P.J. (2012) Massage increases oxytocin and reduces adrenocorticotropin hormone in humans. Alternative Therapies in Health and Medicine, 18(6),11-18.

79. Feldreich, A., Ernberg, M. and Rosén, A., 2016. Reduction in maximum pain after surgery in temporomandibular joint patients is associated with decreased betaendorphin levels-a pilot study. International Journal of Oral and Maxillofacial Surgery, 46(1), 97-103

80. Field T, Hernandez-Reif M, Diego M, Schanberg S, Kuhn C (2005) Cortisol decreases and serotonin and dopamine increase following massage therapy. Int J Neuroscience, 115 (10), 1397-1413.

81. Lindgren, L., Rundgren, S., Winso, O., Lehtipalo, S., Wiklund, U., Karlsson, M.,Stenlund, H., Jacobsson, C. and Brulin C. (2010) Physiological responses to touch massage in healthy volunteers. Autonomic Neuroscience-Basic \& Clinical, 158(1-2), 105-110.

82. Challis, J.R., Sloboda, D., Matthews, S.G., Holloway, A., Alfaidy, N., Patel, F.A., Whittle, W., Fraser, M., Moss, T.J., Newnham, J. (2001) The fetal placental hypothalamic-pituitary-adrenal (HPA) axis, parturition and postnatal health. Molecular and Cellular Endocrinology, 185, (1-2), 135-144. 
83. Liggins, G.C. (1994) The role of cortisol in preparing the fetus for birth. Reproduction, Fertility and Development. 6(2), 141-150.

84. Buss C, Davis EP, Shahbaba B, Pruessner JC, Head K. and Sandman, C.A. (2012) Maternal cortisol over the course of pregnancy and subsequent child amygdala and hippocampus volumes and affective problems. Proc Natl Acad Sci U S A 109: E13121319.

85. Lindfors, P. and Lundberg, U. (2002) Is low cortisol release an indicator of positive health? Stress Health, 18 (4), 153-160.

86. Uvnas-Moberg, K., Arn, I. and Magnusson, D. (2005) The psychobiology of emotion:the role of the oxytocinergic system. (International Journal of Behavioural Medicine, 12 (2), 59-65.

87. Ghaffari, F. and Ghaznein, T.P. (2010) The Reflexology of Sole on Tiredness Intensity in Pregnant Women. Caspian Journal of Internal Medicine, 1(2), 58-62.

88. Gianoulakis, C., Dai, X. and Brown, T. (2003) Effect of Chronic Alcohol Consumption on the Activity of the Hypothalamic-Pituitary-Adrenal Axis and Pituitary $\beta$-Endorphin as a Function of Alcohol Intake, Age, and Gender. Alcoholism: Clinical and Experimental Research, 27 (3), 410-423.

89. Lovallo, W.R., Whitsett, T.L., al'Absi, M., Sung, B.H., Vincent, A.S. and Wilson, M.F. (2005) Caffeine stimulation of cortisol secretion across the waking hours in relation to caffeine intake levels. Psychosomatic Medicine, 67 (5), 734-739.

90. DiPietro, J.A., Costigan, K.A., Kivlighan, K.T., Chen, P. and Laudenslager, M.L. (2011) Maternal salivary cortisol differs by fetal sex during the second half of pregnancy. Psychoneuroendocrinology, 36(4), 588-591.

91. Obel, C., Hedegaard, M., Henriksen, T.B., Secher, N.J., Olsen, J. and Levine, S. (2005) Stress and salivary cortisol during pregnancy. Psychoneuroendocrinology, 30 (7), 647-656. 
Figure 1: CONSORT flow and retention diagram of participants progress throughout the pilot RCT

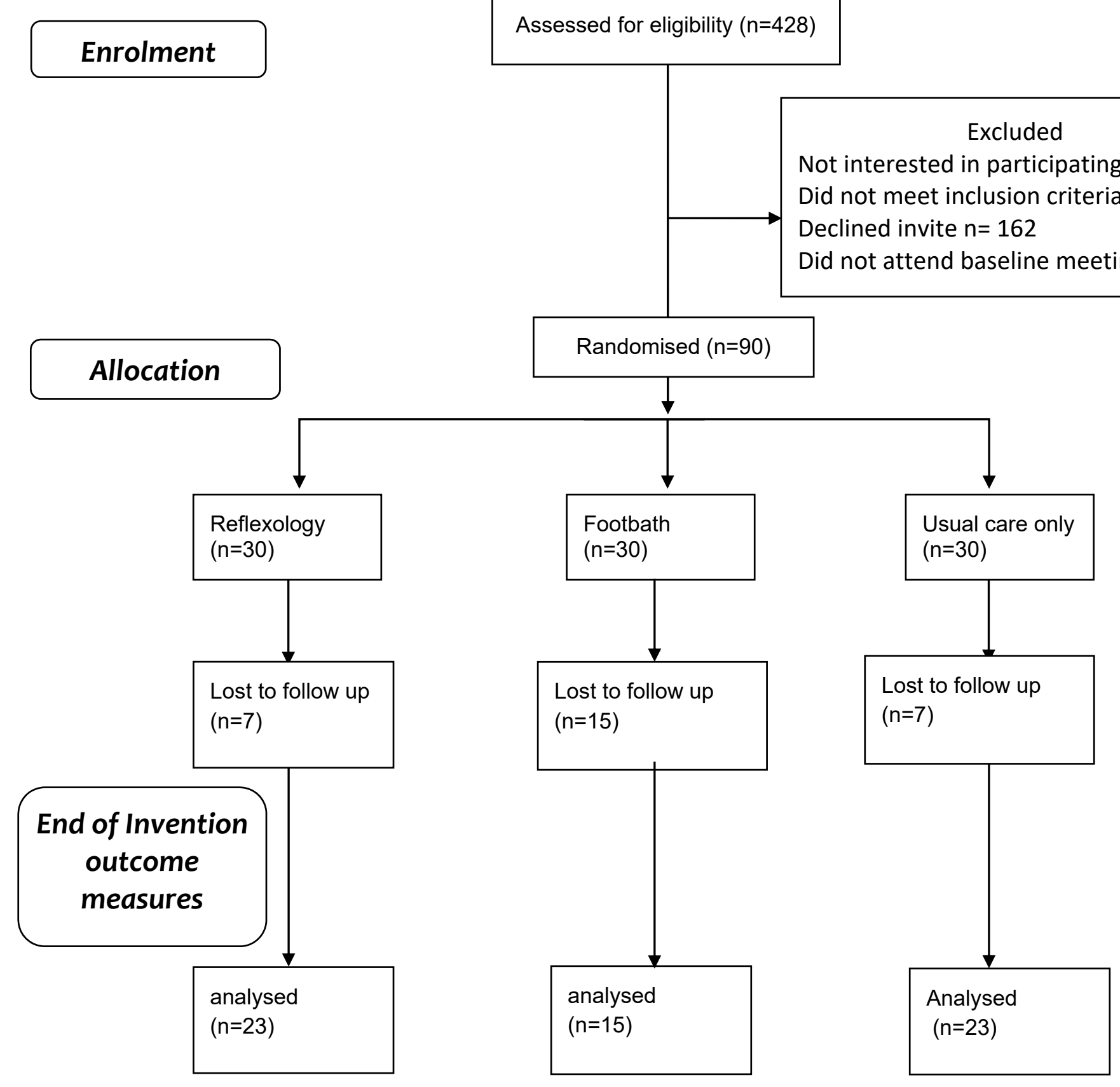

$$
\text { Assessed for eligibility }(n=428)
$$

Excluded

Not interested in participating $n=114$

Did not meet inclusion criteria $\mathrm{n}=52$

Declined invite $\mathrm{n}=162$

Did not attend baseline meeting $n=10$ 
Table 1 Inclusion and exclusion criteria for the CAM in pregnancy study

\begin{tabular}{|c|c|}
\hline Inclusion Criteria & Exclusion Criteria \\
\hline First time pregnant women & $\begin{array}{l}\text { Women pregnant with more than } \\
\text { one baby }\end{array}$ \\
\hline$\geq 18$ years of age & Smokers \\
\hline $\begin{array}{l}\text { Presence of low back pain and/or } \\
\text { pelvic pain }\end{array}$ & Women with neurological diseases \\
\hline 26-29 weeks gestation & $\begin{array}{l}\text { Deep Vein Thrombosis (DVT) } \\
\text { sufferers }\end{array}$ \\
\hline \multirow[t]{11}{*}{$\begin{array}{l}\text { Able to understand written and } \\
\text { verbal English }\end{array}$} & Fungal foot infections or verrucae \\
\hline & Currently using CAM therapies \\
\hline & Placenta Previa Grade 3 or 4 \\
\hline & $\begin{array}{l}\text { Already participating in a research } \\
\text { study }\end{array}$ \\
\hline & $\begin{array}{l}\text { Any serious spinal pathology e.g. } \\
\text { cancer, cauda equina, infection in } \\
\text { the spine }\end{array}$ \\
\hline & Previous road traffic collision \\
\hline & $\begin{array}{l}\text { Previous surgery to the hip, back or } \\
\text { pelvic region }\end{array}$ \\
\hline & $\begin{array}{l}\text { Inflammatory arthritis, e.g. } \\
\text { rheumatoid arthritis }\end{array}$ \\
\hline & Diabetes/Gestational diabetes \\
\hline & Cardiac related problems \\
\hline & $\begin{array}{l}\text { Women whom the midwife deems } \\
\text { unable to participate }\end{array}$ \\
\hline
\end{tabular}


Table 2 Mean baseline characteristics of the CAM in Pregnancy Study participants at 27 weeks gestation

\begin{tabular}{|c|c|c|c|c|}
\hline 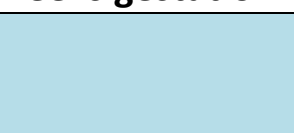 & $\begin{array}{l}\text { Usual care } \\
(n=23)\end{array}$ & $\begin{array}{l}\text { Reflexology } \\
(n=23)\end{array}$ & $\begin{array}{l}\text { Foot bath } \\
(n=15)\end{array}$ & P-Value \\
\hline Age (+/- SD) & $30.4(5.8)$ & $30.4(4.9)$ & $31.3(5.5)$ & 0.854 \\
\hline $\mathrm{BMI}(+/-\mathrm{SD})$ & $25.7(4.4)$ & 26.1 (3.9) & $25.1(4.1)$ & 0.778 \\
\hline $\begin{array}{l}\text { Gestational } \\
\text { age (+/-SD) }\end{array}$ & $27.1(0.9)$ & $27.9(0.9)$ & $28.3(1.0)$ & 0.994 \\
\hline $\begin{array}{r}\text { Pain type (\%) } \\
L B P\end{array}$ & $52.2(12 / 23)$ & $52.2(12 / 23)$ & $53.3(8 / 15)$ & 0.989 \\
\hline$P P$ & $4.3(1 / 23)$ & $4.3(1 / 23)$ & 0 & \\
\hline$\angle B P G P$ & $43.5(10 / 23)$ & $43.5(10 / 23)$ & $46.7(7 / 15)$ & \\
\hline $\begin{array}{l}\text { Gestation at } \\
\text { pain onset (+/- } \\
\text { SD) }\end{array}$ & $17.2(5.3)$ & $18.4(4.9)$ & 18.7 (3.9) & 0.845 \\
\hline $\begin{array}{l}\text { \% with } \\
\text { previous } \\
\text { LBPGP }\end{array}$ & $47.8(11 / 23)$ & $60.2(14 / 23)$ & $33.3(5 / 15)$ & 0.304 \\
\hline $\begin{array}{l}\text { State anxiety } \\
(+/-S D)\end{array}$ & $46.5(4.3)$ & $43.5(5.3)$ & $44.2(3.8)$ & 0.263 \\
\hline $\begin{array}{l}\text { Mean heart } \\
\text { rate (+/-SD) } \\
95 \% \mathrm{Cl}\end{array}$ & & $\begin{array}{l}81.5(8.8) \\
{[80.0-83.0]}\end{array}$ & $\begin{array}{l}81.3(10.2) \\
{[79.0-83.5]}\end{array}$ & 0.737 \\
\hline $\begin{array}{l}\text { Mean systolic } \\
\text { blood pressure } \\
\text { (+/-SD) } 95 \% \mathrm{Cl}\end{array}$ & & $\begin{array}{l}118.4(8.9) \\
{[116.9-120.0]}\end{array}$ & $\begin{array}{l}113.4(10.7) \\
{[111.0-115.8]}\end{array}$ & 0.190 \\
\hline $\begin{array}{l}\text { Mean diastolic } \\
\text { blood pressure } \\
\text { (+/-SD) } 95 \% \mathrm{Cl}\end{array}$ & & $\begin{array}{l}70.4(7.3) \\
{[69.1-71.7]}\end{array}$ & $\begin{array}{l}65.6(6.7) \\
{[64.0-67.0]}\end{array}$ & 0.833 \\
\hline
\end{tabular}


Table 3 Mean VAS frequency and intensity scores (+/-SD) at baseline and week six of the CAM in pregnancy study intervention period from mean gestation 27 weeks to 33 weeks

\begin{tabular}{lllllll}
\hline & $\begin{array}{l}\text { VAS } \\
\text { frequency } \\
\text { baseline }\end{array}$ & $\begin{array}{l}\text { VAS } \\
\text { frequency } \\
\text { week 6 }\end{array}$ & $\begin{array}{l}\text { Change } \\
\text { over 6 } \\
\text { week } \\
\text { period }\end{array}$ & $\begin{array}{l}\text { VAS } \\
\text { intensity } \\
\text { baseline }\end{array}$ & $\begin{array}{l}\text { VAS } \\
\text { intensity } \\
\text { week 6 }\end{array}$ & $\begin{array}{l}\text { Change } \\
\text { over 6 } \\
\text { week } \\
\text { period }\end{array}$ \\
\hline $\begin{array}{l}\text { Usual Care } \\
(\mathrm{n}=23)\end{array}$ & $5.86(2.54)$ & $5.50(2.81)$ & $\begin{array}{l}-0.36 \\
(2.94)\end{array}$ & $5.12(2.19)$ & $5.33(2.69)$ & $\begin{array}{l}0.21 \\
(3.07)\end{array}$ \\
\hline $\begin{array}{l}\text { Reflexology } \\
(\mathrm{n}=23)\end{array}$ & $7.05(2.36)$ & $5.42(2.80)$ & $\begin{array}{l}-1.64 \\
(2.97)^{*}\end{array}$ & $5.81(2.02)$ & $5.14(2.65)$ & -0.67 \\
\hline $\begin{array}{l}\text { Footbath } \\
\text { (n=15) }\end{array}$ & $5.65(2.28)$ & $6.13(2.86$ & $\begin{array}{l}0.48 \\
(3.28)\end{array}$ & $4.68(2.31)$ & $5.63(2.27)$ & 0.95 \\
\hline
\end{tabular}

*denotes a clinically important change

Table 4 Beta-endorphin concentrations ( $\mathrm{ng} / \mathrm{ml})$ (+/-SD) at baseline and week six of the CAM in pregnancy study intervention period from mean gestation 27 weeks to 33 weeks

\begin{tabular}{|c|c|c|c|c|}
\hline & $\begin{array}{l}\text { Beta-endorphin } \\
\text { baseline }\end{array}$ & $\begin{array}{l}\text { Beta-endorphin } \\
\text { post treatment } 1\end{array}$ & $\begin{array}{l}\text { Beta-endorphin } \\
\text { pre- treatment } 6\end{array}$ & $\begin{array}{l}\text { Beta-endorphin } \\
\text { post treatment } \\
6 / \text { end of } \\
\text { intervention }\end{array}$ \\
\hline $\begin{array}{l}\text { Usual Care } \\
(n=23)\end{array}$ & $\begin{array}{l}4.29(3.24) \\
95 \% \text { Cl } 2.88- \\
5.69\end{array}$ & & & $\begin{array}{l}4.72(3.28) \\
95 \% \mathrm{Cl} 3.30- \\
6.14\end{array}$ \\
\hline $\begin{array}{l}\text { Reflexology } \\
(n=23)\end{array}$ & $\begin{array}{l}4.94(2.62) \\
95 \% \mathrm{Cl} 4.50- \\
5.38 \\
\end{array}$ & $\begin{array}{l}4.60(3.21) \\
95 \% \mathrm{Cl} 4.06- \\
5.14\end{array}$ & $\begin{array}{l}4.47(3.10) \\
95 \% \mathrm{Cl} 3.95- \\
4.99\end{array}$ & $\begin{array}{l}4.19 \text { (2.99) } \\
95 \% \text { Cl } 3.69- \\
4.69\end{array}$ \\
\hline $\begin{array}{l}\text { Footbath } \\
(n=15)\end{array}$ & $\begin{array}{l}3.79(2.74) \\
95 \% \text { Cl } 3.22- \\
4.37\end{array}$ & $\begin{array}{l}3.85(2.97) \\
95 \% \text { Cl } 3.22- \\
4.47\end{array}$ & $\begin{array}{l}3.52(2.75) \\
95 \% \text { Cl } 2.94- \\
4.10\end{array}$ & $\begin{array}{l}4.13(3.30) \\
95 \% \mathrm{Cl} 3.44- \\
4.83\end{array}$ \\
\hline
\end{tabular}

Table 5 Cortisol concentrations $(\mu \mathrm{g} / \mathrm{dL})(+/-\mathrm{SD})$ at baseline and week six of the CAM in pregnancy study intervention period from mean gestation 27 weeks to 33 weeks

\begin{tabular}{lllll}
\hline & $\begin{array}{l}\text { Cortisol } \\
\text { baseline }\end{array}$ & $\begin{array}{l}\text { Cortisol post } \\
\text { treatment 1 }\end{array}$ & $\begin{array}{l}\text { Cortisol pre- } \\
\text { treatment 6 }\end{array}$ & $\begin{array}{l}\text { Cortisol post } \\
\text { treatment } \\
\text { 6/end of } \\
\text { intervention }\end{array}$ \\
\hline Usual Care & $0.226(0.33)$ & & $0.297(0.38)$ \\
\hline
\end{tabular}




\begin{tabular}{lllll}
\hline$(\mathrm{n}=23)$ & $95 \% \mathrm{Cl} 0.084-$ & & $95 \% \mathrm{Cl} 0.133-$ \\
& 0.269 & & & 0.460 \\
\hline Reflexology & $0.170(0.107)$ & $0.146(0.060)$ & $0.187(0.047)$ & $0.202(0.081)$ \\
$(n=23)$ & $95 \% \mathrm{Cl} 0.129-$ & $95 \% \mathrm{Cl} 0.120-$ & $95 \% \mathrm{Cl} 0.166-$ & $95 \% \mathrm{Cl} 0.166-$ \\
& 0.224 & 0.173 & 0.208 & 0.238 \\
\hline Footbath & $0.129(0.063)$ & $0.145(0.062)$ & $0.197(0.065)$ & $0.170(0.073)$ \\
$(n=15)$ & $95 \% \mathrm{Cl} 0.094-$ & $95 \% \mathrm{Cl} 0.112-$ & $95 \% \mathrm{Cl} 0.161-$ & $95 \% \mathrm{Cl} 0.130-$ \\
& 0.164 & 0.180 & 0.232 & 0.210 \\
\hline
\end{tabular}

Figure 2 Average \% change (SEM) in salivary beta-endorphin concentration from baseline to the end of the 6-week CAM in Pregnancy Study intervention period

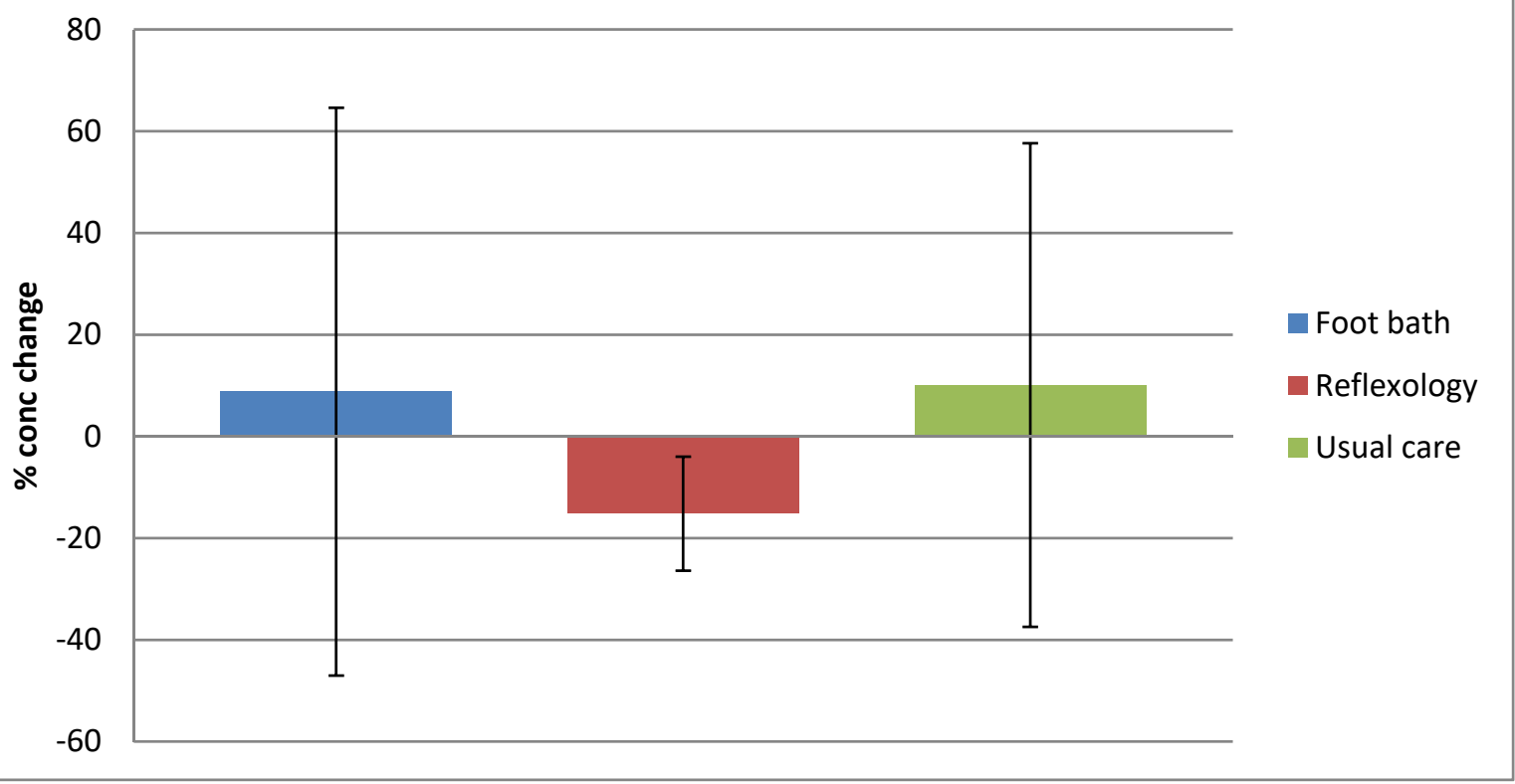




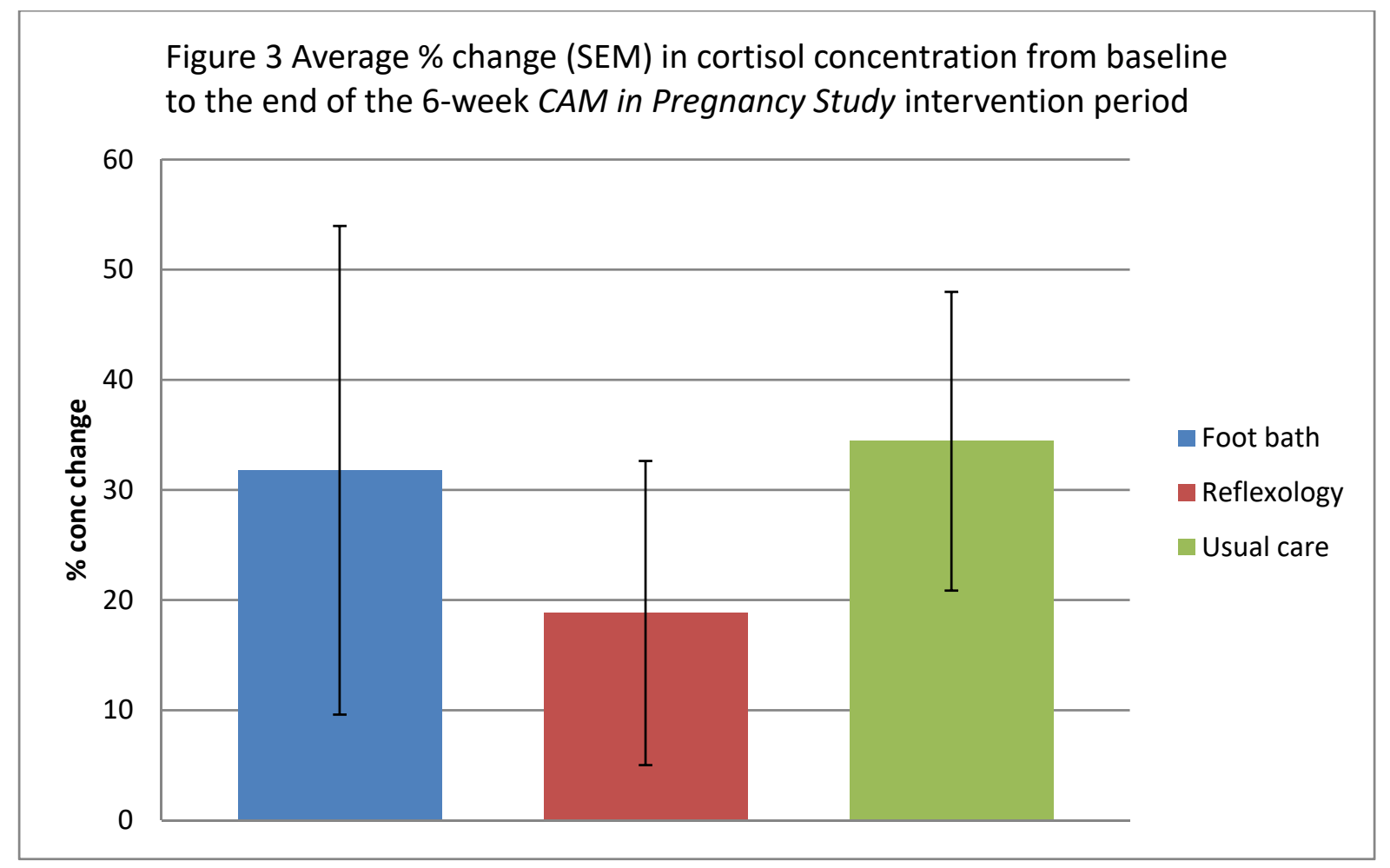

